\title{
E-SERVICE QUALITY HOTEL PANGERAN PEKANBARU PADA WEBSITE TRAVELOKA
}

\author{
Ervina Wardiyanti \\ Prodi Pariwisata, Fakultas Ilmu Budaya, Universitas Gadjah Mada, Indonesia \\ Email: ervina.wardiyanti@gmail.com \\ Intan Purwandani \\ Prodi Pariwisata, Fakultas Ilmu Budaya, Universitas Gadjah Mada, Indonesia \\ Email: intanpurwandani@ugm.ac.id
}

\begin{abstract}
Hotel Pangeran Pekanbaru is a 4-star hotel in Pekanbaru City which uses several Online Travel Agent (OTA) companies as online reservation media, with one of the highest reservation comes from Traveloka. The purpose of this study is to assess the electronic quality service of Traveloka's website as an online reservation media at Hotel Pangeran Pekanbaru. The six dimensions of e-service quality by Tsang et al. (2010) include: (1) Website Function; (2) Quality and Information Content; (3) Need Fulfillment and Responsiveness; (4) Safety and Security; (5) Appearance and Presentation; and (6) Customer Relationships are implemented as a measure of the quality of an OTA's electronic service. This research is a descriptive quantitative study using data collection methods of survey and online questionnaire as a research tool. Online questionnaires were distributed to 100 guests of Hotel Pangeran Pekanbaru who had made online reservations through the Traveloka website. The results of this study indicate that the respondents' perceptions of Traveloka website's e-service quality as an online reservation media for Hotel Pangeran Pekanbaru were classified as "high" with an average score of 3.56. Although the overall value of e-service quality on the Traveloka website is classified as "high", at the e-service quality value from the respondent's profile perspective, there is a minority group of $1 \%$ who answered that the quality of electronic services was in the "medium" category.
\end{abstract}

Keywords: electronic service quality, online travel agent, Traveloka, online reservation, online booking

\section{Pendahuluan}

Seiring dengan perkembangan teknologi yang semakin modern, informasi dapat dengan mudah didapat dengan adanya internet. Internet membuka berbagai 
peluang untuk penggunanya, termasuk melakukan transaksi jual-beli. Fenomena ini membuka berbagai peluang bagi pelaku bisnis untuk mengintegrasikan usahanya dengan teknologi internet atau dapat disebut dengan bisnis e-commerce. E-commerce atau perdagangan elektronik dapat ditemukan pada berbagai jenis bisnis seperti retail, transportasi, food and beverage dan tidak terkecuali jasa akomodasi. Menurut Marcussen (2008), dalam industri pariwisata, pemesanan hotel adalah pendapatan terbesar kedua berdasarkan volume penjualan yang dihasilkan melalui saluran daring (Peterkin, 2014). Oleh karena itu, terdapat berbagai saluran daring yang menawarkan fasilitas pemesanan hotel. Salah satunya adalah Online Travel Agent (OTA).

Traveloka adalah salah satu OTA yang beroperasi di Indonesia. Menurut situs Alexa, website www.traveloka.com merupakan situs booking tiket online di Indonesia yang paling sering dikunjungi (Sastika, 2016, p. 650). Saat ini Traveloka tidak hanya menawarkan layanan pemesanan tiket pesawat, tetapi mencakup tiket atraksi wisata, pemesanan transportasi darat, serta pemesanan akomodasi sehingga pengguna Traveloka dapat memesan jasa akomodasi tanpa harus menghubungi pihak hotel. Disisi lain, hal tersebut dapat menguntungkan pihak hotel dengan adanya saluran distribusi yang dapat diakses dengan jangkauan yang luas dan cepat oleh wisatawan. O'Connor dan Frew (2004) mengemukakan bahwa salah satu keuntungan utama dari distribusi internet untuk hotel adalah pengurangan biaya (Yoon, 2011. P. 2).

Agar memiliki saluran distribusi internet melalui Traveloka, pihak hotel harus menjalin kerjasama dengan OTA yang terkait. Setiap usaha akomodasi tidak terbatas untuk menjalin kerjasama dengan Traveloka, dari kelas tidak berbintang hingga berbintang 5. Salah satu hotel yang menjalin kerjasama dengan Traveloka untuk menjualkan jasa akomodasi adalah Hotel Pangeran Pekanbaru. 
Hotel Pangeran Pekanbaru merupakan salah satu hotel dengan jumlah kamar terbanyak di Kota Pekanbaru, Provinsi Riau (Oktariani dan Achnes, 2016). Agar memudahkan tamu memesan kamar, Hotel Pangeran Pekanbaru memiliki berbagai saluran distribusi akomodasi. Tamu dapat memesan kamar dengan cara walk-in booking, menghubungi langsung pihak hotel melalui telepon atau Whatsapp, serta melalui OTA. Hingga saat ini, Hotel Pangeran Pekanbaru menjualkan kamarnya melalui OTA antara lain: Traveloka, Pegipegi, Tiket.com, Expedia.com, dan Agoda.com. Namun dari kelima OTA tersebut, Traveloka menjadi OTA dengan tingkat pemesanan tertinggi.

Hasil wawancara dengan bagian e-commerce Hotel Pangeran Pekanbaru menunjukkan bahwa jika sebuah hotel ingin menjualkan kamarnya pada Traveloka, maka akan membayar komisi sebesar 15\% hingga 20\%. Jika dibandingkan dengan pemesanan langsung ke hotel, pemesanan tamu melewati Traveloka akan menghasilkan pendapatan yang lebih sedikit. Hingga saat ini, Traveloka menjadi media dengan jumlah reservasi terbanyak diantara perusahaan OTA lain yang menjadi media reservasi di Hotel Pangeran Pekanbaru.

Tsang dkk (2010, p. 369) menyimpulkan bahwa berbagai peneliti telah merumuskan berbagai bentuk pengukuran e-service quality untuk situs web ecommerce (Kaynama dan Black, 2000; Loiacono dkk, 2000; Wolfinbarger dan Gilly, 2013). Pada penelitian kali ini penulis akan menggunakan 6 skala dimensi e-service quality yang dirumuskan oleh Tsang, dkk (2010) untuk mengevaluasi kualitas layanan elektronik sebuah OTA. Enam dimensi tersebut antara lain adalah: (1) Website Functionality; (2) Information Quality and Content; (3) Fulfillment and Responsiveness; (4) Safety and Security; (5) Appearance and Presentation; (6) Customer Relationship (Tsang, dkk, 2010, p. 1)

Sehubungan dengan itu, menjadi pertanyaan bagi penulis dan manajemen Hotel Pangeran Pekanbaru perihal mengapa Traveloka menjadi OTA dengan jumlah 
reservasi terbanyak. Pihak Traveloka juga tidak menyediakan hasil kepuasan pelanggan menggunakan situs web Traveloka sebagai media reservasi kepada manajemen Hotel Pangeran Pekanbaru. Selain itu, Hotel Pangeran Pekanbaru juga merencanakan dibuatnya situs web resmi hotel yang dapat mengakomodir reservasi tamu di masa yang akan datang ${ }^{1}$. Pengukuran Electronic Service Quality (e-service quality) situs web Traveloka sebagai media reservasi OTA terpopuler di Hotel Pangeran Pekanbaru dilakukan untuk menjabarkan dinamika kualitas layanan dari situs web Traveloka dan menjawab pertanyaan manajemen hotel perihal acuan situs web reservasi yang baik.

\section{Tinjauan Pustaka}

Kualitas sebuah layanan atau Service Quality merupakan salah satu faktor penting dalam persaingan bisnis, tidak terkecuali bisnis e-commerce pada industri pariwisata. Hal tersebut dikarenakan, kualitas sebuah layanan dianggap menjadi faktor utama keberhasilan organisasi, terutama pada industri berbasis jasa (Ding dkk, 2020, p. 1). Service quality menurut Pasuruman dkk (2018) merupakan fungsi dari perbedaan antara layanan yang diharapkan dan persepsi pelanggan mengenai layanan yang diterima (Shen \& Yahya, 2020, p. 2). Dalam konteks bisnis e-commerce, beberapa peneliti (Van Riel, Semeijn, \& Janssen, 2003) berpendapat bahwa ketika konsumen mengunjungi sebuah situs web, mereka lebih cenderung mengevaluasi layanan yang dirasakan dalam hal keseluruhan proses dan hasil, daripada menilai setiap subproses secara detail (Tsang $d k k, 2010$, p. 309). Oleh karena itu, beberapa peneliti telah berusaha untuk merumuskan dimensi kualitas layanan elektronik, khususnya untuk diaplikasikan pada layanan berbasis situs web.

\footnotetext{
${ }^{1}$ Hasil wawancara dengan departemen IT Hotel Pangeran Pekanbaru, 3 Juli 2020
} 
Salah satu dari beberapa kelompok peneliti pertama yang mengembangkan dimensi kualitas layanan elektronik atau e-service quality merupakan Kaynama dan Black (2000), peneliti tersebut mengusulkan tujuh kriteria E-QUAL yang dipilih secara khusus karena mirip dengan lima dimensi SERVQUAL. Namun, tidak ada item skala yang telah dikembangkan untuk setiap dimensi spesifik dari konstruksi multidimensi ini. Setelah itu 12 skala WebQual dikembangkan oleh Loiacono, Watson, dan Goodhue (2002), skala yang memiliki tujuan utama sebagai penghasil informasi untuk perancang situs web daripada untuk mengukur kualitas layanan seperti yang dirasakan oleh pelanggan. Kemudian Tsang, Lai dan Law (2010, p. 308) menyadari kurangnya literatur mengenai penerapan e-service quality untuk agen perjalanan online, sehingga mengembangkan enam dimensi yang melandasi pengukuran eservice quality untuk OTA yaitu: (1) Website Functionality; (2) Information Quality and Content; (3) Fulfillment and Responsiveness; (4) Safety and Security; (5) Appearance and Presentation; dan (6) Customer Relationship.

Penelitian-penelitian sebelumnya mengenai penerapan pengukuran e-service quality pada industri pariwisata, sudah beberapa kali dilakukan. Kim dkk (2012) mengevaluasi pengukuran e-service quality dalam pemesanan hotel daring berbasis situs web perusahaan. Selain itu, literatur mengenai pengukuran e-service quality terhadap situs web OTA juga sudah tersedia seperti penelitian untuk mengetahui pengaruh WebQual 4.0 terhadap keputusan pembelian di situs web Traveloka (Sastika, 2016) atau penelitian komprehensif mengenai kualitas layanan online, menerapkan teori pada penawaran perjalanan online, dan melaporkan studi empiris tentang persepsi kualitas layanan pra-transaksi dari tiga situs web perjalanan (Van Riel dkk, 2004). Namun, dari literatur-literatur terdahulu, dapat disimpulkan bahwa masih terbatasnya perkembangan literasi mengenai digitalisasi pada bidang hospitalitas yang menjadi salah satu motivasi pengkajian dalam penelitian ini. 
Identifikasi kualitas layanan elektronik OTA sebagai media reservasi hotel menjadi perbedaan penelitian ini dari penelitian-penelitian sebelumnya.

\section{Metode Penelitian}

\section{Jenis Penelitian}

Penelitian ini menggunakan pendekatan kuantitatif. Pendekatan kuantitatif adalah penelitian yang menguji teori dengan meninjau variabel-variabel terukur yang datanya dapat dianalisis secara statistik (Cresswell, 2014, p. 4). Dalam konteks penelitian ini, teori yang diujikan adalah e-service quality karya Tsang dkk (2010) dengan mengukur enam variabel yang ada pada teori tersebut. Kuesioner daring akan disebarkan kepada responden untuk dapat memperoleh data berupa tanggapan pengguna terhadap e-service quality situs web Traveloka sebagai media pemesaran akomodasi daring di Hotel Pangeran Pekanbaru. Pengukuran tanggapan responden akan dilakukan dengan kuesioner berskala likert. Tanggapan dari kuesioner skala likert tersebut akan dihitung nilai rata-ratanya sesuai dengan kelompok variabel yang diujikan.

\section{Teknik Pengumpulan Data}

Teknik pengumpulan data yang dilakukan berupa observasi, wawancara, survei dan studi pustaka. Observasi dan wawancara dilakukan untuk mendapatkan informasi lebih dalam mengenai peran Traveloka dalam menjadi perantara reservasi daring di Hotel Pangeran Pekanbaru. Selain itu, data yang didapatkan dari tinjauan pustaka bertujuan untuk memperkuat keabsahan teori-teori yang digunakan dalam penelitian, Terakhir, kegiatan survei dilakukan untuk mendapatkan tanggapan tamu mengenai $e$-service quality situs web Traveloka sebagai media reservasi daring di Hotel Pangeran Pekanbaru. 
Survei digunakan untuk mendapatkan data berupa tanggapan dari tamu yang telah melakukan reservasi daring melalui Traveloka di Hotel Pangeran Pekanbaru. Narasumber akan dipilih dengan metode purposive sampling. Metode purposive sampling atau juga disebut judgment sampling adalah pemilihan responden karena kualitas yang dimiliki peserta tersebut (Etikan dkk, 2016, p. 2). Subjek penelitian merupakan narasumber yang telah memenuhi kriteria tertentu yaitu tamu hotel Pangeran Pekanbaru yang menginap dan melakukan reservasi melalui situs web Traveloka. Dalam penelitian ini, sebanyak 100 orang tamu Hotel Pangeran yang pernah melakukan reservasi melalui situs web Traveloka akan diambil untuk dijadikan responden penelitian.

\section{Operasionalisasi Konsep E-Service Quality}

Kuesioner terdiri dari 2 bagian. Bagian pertama terdiri dari pertanyaanpertanyaan mengenai profil narasumber dan bagian kedua adalah mengenai $e$-service quality. Pada bagian e-service quality, enam dimensi dan indikator orisinal yang dikembangkan oleh Tsang dkk (2010, p. 306) yang bertujuan untuk mengevaluasi kualitas layanan elektronik agen perjalanan daring akan diimplementasikan dalam penelitian penulis. Hal tersebut karena enam dimensi e-service quality, (1) Fungsi Situs Web; (2) Kualitas dan Konten Informasi; (3) Pemenuhan Kebutuhan dan Responsivitas; (4) Keselamatan dan Keamanan; (5) Penampilan dan Presentasi; dan (6) Hubungan kepada Pelanggan, dapat diimplementasikan ke dalam konteks pemesanan akomodasi Hotel Pangeran Pekanbaru melalui situs web Traveloka. Selain itu, beberapa gambar tampilan situs web ditautkan untuk menjadi referensi bagi responden. Hal tersebut dilakukan untuk menyatukan persepsi responden dengan fokus penelitian mempertimbangkan luasnya cakupan layanan yang ditawarkan oleh situs web Traveloka. 


\section{Analisis Data}

Proses analisis data terdiri dari tiga tahap yaitu pemeriksaan data, pengkodean dan pengelompokkan data, serta pengolahan data. Pada tahap pemeriksaan, seluruh data yang didapatkan dari hasil survei dievaluasi untuk memastikan semua jawaban kuesioner telah dijawab dengan lengkap atau tidak ada kesalahan dan kekurangan dalam hasil jawaban kuesioner. Setelah mendapatkan hasil kuesioner dari 100 responden, pengkodean hasil kuesioner akan dilakukan pada perangkat lunak IBM SPSS 22. Pengkodean dilakukan untuk mengelompokkan jawaban responden pada kategori tertentu. Terakhir, pada tahap pengolahan data kuesioner akan diuji validitas dan reliabilitas dari 30 orang responden. Setelah uji validitas dan reliabilitas, analisis data dengan pendekatan deskriptif dilakukan. Penelitian deskriptif dilakukan untuk mengetahui nilai variabel yang sifatnya independen, baik satu atau lebih variabel, tanpa membuat hubungan maupun perbandingan dengan variabel lain (Creswell, 2014).

Proses pengolahan data dilakukan dengan cara mengalikan frekuensi (f) dengan nilai bobot dari setiap tingkatan skala likert. Nilai bobot tersebut antara lain adalah: nilai 1 untuk mewakili Sangat Tidak Setuju (STS), nilai 2 mewakili Tidak Setuju (TS), nilai 3 mewakili Setuju (S), dan nilai 4 mewakili Sangat Setuju (SS). Setelah itu, hasil perkalian frekuensi (f) dan nilai bobot akan menjadi skor (N) setiap item pernyataan. Jika skor $(\mathrm{N})$ sudah diperoleh, nilai rata-rata per item akan dihitung dengan cara membagi $\mathrm{N}$ dengan jumlah responden yang ada. Selain itu, nilai rata-rata pada setiap dimensi juga akan dilakukan dengan cara menjumlahkan seluruh nilai rata-rata pada satu dimensi dan dibagi dengan jumlah item yang ada. Nilai rata-rata per item dan dimensi akan dianalisis secara deskriptif sesuai dengan kriteria interpretasi skala penilaian, seperti dibawah ini:

- Skor untuk kategori tinggi : 3,00 - 4,00

- Skor untuk kategori sedang: 2,00 - 3,00

- Skor untuk kategori rendah: 1,00 - 2,00 
Berdasarkan skala penelitian diatas, maka dapat disimpulkan konstruksi berpikir seperti dibawah ini:

- Jika skor (nilai rata-rata) mendekati angka 4,00, maka semakin positif responden menunjukan tanggapan terhadap dimensi $e$-service quality situs web Traveloka sebagai media reservasi daring Hotel Pangeran Pekanbaru.

- Sebaliknya, jika skor semakin mendekati angka 1,00, maka tanggapan responden semakin negatif terhadap dimensi yang terkait.

\section{Hasil dan Pembahasan}

\section{Karakteristik Responden}

Mayoritas responden memiliki karakteristik berjenis kelamin pria, berusia usia 17-24 tahun, berasal dari Provinsi Riau, berpendidikan perguruan tinggi, bekerja sebagai pegawai perusahaan swasta, memiliki pendapatan bulanan sebanyak Rp 1.000.000 hingga Rp 10.000.000, dan jarang menggunakan Traveloka sebagai media reservasi akomodasi (tabel 1).

Tabel 1. Karakteristik Responden

\begin{tabular}{lcc}
\hline \multicolumn{1}{c}{ Karakteristik } & F & \% \\
\hline Jenis Kelamin & 73 & $73 \%$ \\
Pria & 27 & $27 \%$ \\
Wanita & & \\
Usia & 40 & $40 \%$ \\
$17-24$ & 27 & $27 \%$ \\
$25-39$ & 33 & $33 \%$ \\
$\geq 40^{2}$ & $33 \%$ \\
\hline
\end{tabular}

\footnotetext{
${ }^{2}$ Usia responden yang melebihi 40 tahun, dibedakan menjadi 3 kategori: 40-56 tahun, 56-64 tahun, lebih dari (>) 64 tahun.

182 JUMPA Volume 8, Nomor 1, Juli 2021
} 


\begin{tabular}{|c|c|c|}
\hline Karakteristik & $\mathbf{F}$ & $\%$ \\
\hline \multicolumn{3}{|l|}{ Provinsi Asal } \\
\hline Riau & 69 & $69 \%$ \\
\hline Luar Riau ${ }^{3}$ & 31 & $31 \%$ \\
\hline \multicolumn{3}{|l|}{ Jenjang Pendidikan } \\
\hline Tamat SMA/SMK/MA & 35 & $35 \%$ \\
\hline Perguruan Tinggi & 65 & $65 \%$ \\
\hline \multicolumn{3}{|l|}{ Profesi } \\
\hline Pegawai Swasta & 42 & $42 \%$ \\
\hline Pelajar/Mahasiswa & 29 & $29 \%$ \\
\hline Lain-lain ${ }^{4}$ & 29 & $29 \%$ \\
\hline \multicolumn{3}{|l|}{ Pendapatan Bulanan } \\
\hline$<\operatorname{Rp} 1.000 .000$ & 21 & $21 \%$ \\
\hline Rp1.000.000-Rp 10.000.000 & 49 & $49 \%$ \\
\hline$>\operatorname{Rp} 10.000 .000$ & 30 & $30 \%$ \\
\hline \multicolumn{3}{|l|}{ Intensitas Penggunaan } \\
\hline Sering ( > 3 kali ) & 40 & $40 \%$ \\
\hline Jarang ( $\leq 2$ kali ) & 60 & $60 \%$ \\
\hline
\end{tabular}

\section{E-service Quality situs web Traveloka sebagai Media Pemesanan Akomodasi Daring Hotel Pangeran Pekanbaru}

Tabel 2 memaparkan penilaian responden terhadap e-service quality situs web Traveloka sebagai media reservasi daring Hotel Pangeran Pekanbaru. Kuesioner terdiri dari 33 item pernyataan yang terbagi ke dalam 6 dimensi dengan skala likert 4

\footnotetext{
${ }^{3}$ Provinsi asal responden yang berada di luar Riau terdiri dari: Sumatera Barat, DKI Jakarta, DI Yogyakarta, Jawa Barat, Jawa Tengah, Jawa Timur, Sumatera Utara, Bali, Kepulauan Riau, dan Banten. 4 Profesi yang tidak termasuk Pegawai Swasta atau Pelajar/Mahasiswa antara lain adalah: Wirausahawan, Pegawai Negeri, Pegawai BUMN, Pekerjaan Profesi Khusus, dan yang tidak bekerja.
} 
tingkatan. Dimensi yang digunakan dalam penelitian ini berhubungan dengan kualitas layanan elektronik situs web Traveloka sebagai media reservasi daring di Hotel Pangeran Pekanbaru.

Tabel 2. E-service Quality situs web Traveloka sebagai media reservasi daring Hotel Pangeran Pekanbaru

\begin{tabular}{llcc}
\hline Kode & \multicolumn{1}{c}{ Dimensi } & Skor & Kategori \\
\hline D1 & Dimensi Fungsionalitas Situs Web & 3,62 & Tinggi \\
D2 & Dimensi Kualitas dan Konten Informasi & 3,55 & Tinggi \\
D3 & Dimensi Pemenuhan Kebutuhan dan & 3,52 & Tinggi \\
& Responsivitas & & \\
D4 & Dimensi Keselamatan dan Keamanan Pengguna & 3,52 & Tinggi \\
D5 & Dimensi Penampilan dan Presentasi & 3,62 & Tinggi \\
D6 & Dimensi Hubungan kepada Pelanggan & 3,54 & Tinggi \\
\hline \multirow{2}{*}{ Total } & 3,56 & Tinggi \\
\hline
\end{tabular}

Dari hasil tersebut dapat disimpulkan bahwa keseluruhan nilai e-service quality dikategorikan "Tinggi" dengan nilai rata-rata total 3,56. Hal tersebut mengindikasikan bahwa penggunaan website Traveloka untuk reservasi Hotel Pangeran Pekanbaru dikarenakan karena kualitas layanan elektronik situs web Traveloka yang memberikan kesan positif. Dimensi Fungsionalitas Situs Web, situs web memberikan informasi yang memadai tentang produk dan layanan hotel, adalah elemen paling penting yang berkontribusi pada kegunaan situs web (Lu dan Yeung, 1998 dalam Ip dkk, 2012, p. 264,), serta Dimensi Penampilan dan Presentasi yang mencerminkan desain dan presentasi situs web dalam hal penggunaan warna, teks, multimedia, serta antarmuka (Tsang dkk, 2010, p. 317) memiliki skor tertinggi yaitu 3,62 . 
Tanggapan yang memiliki skor terendah yaitu berada pada Dimensi Keselamatan dan Keamanan Pengguna serta Dimensi Pemenuhan Kebutuhan dan Responsivitas. Kedua dimensi tersebut memiliki skor 3,52, masih dalam kategori “Tinggi” tetapi lebih rendah jika dibandingkan dengan skor dimensi lainnya. Dimensi tersebut menggambarkan bagaimana perusahaan memenuhi janji layanan dan menangani masalah pelanggan (Zemblyte, 2015 dalam Putri dkk, 2020, p. 1) serta mencerminkan kepercayaan pengguna akan keamanan informasi pribadi yang diberikan pada situs web OTA.

\section{E-service Quality berdasarkan Karakteristik Responden}

Setelah dieksplorasi secara menyeluruh hasil penelitian menunjukkan beberapa perbedaan rata-rata e-service quality setiap komponen antara karakteristik responden. Hasil kuesioner dari 100 responden akan dibagi berdasarkan jenis kelamin, usia, daerah asal, jenjang pendidikan, profesi, pendapatan bulanan, dan intensitas pengguna menggunakan Traveloka sebagai media reservasi akomodasi. Hal tersebut dilakukan untuk memaparkan perbedaan nilai-nilai tersebut berdasarkan profil responden.

Tabel 3. E-service Quality berdasarkan karakteristik responden

\begin{tabular}{lcccccccccc}
\hline \multirow{2}{*}{ Karakteristik } & f & \multicolumn{3}{c}{ Skor Per-Dimensi } & & & & Skor & Kategori \\
\cline { 3 - 7 } & & D1 & D2 & D3 & D4 & D5 & D6 & Total & \\
Jenis Kelamin & & & & & & & & & \\
Pria & 73 & 3,60 & 3,55 & 3,50 & 3,53 & 3,62 & 3,57 & 3,56 & Tinggi \\
Wanita & 27 & 3,65 & 3,54 & 3,59 & 3,49 & 3,64 & 3,47 & 3,56 & Tinggi \\
Rentang Umur & & & & & & & & & \\
17-24 & 40 & 3,57 & 3,55 & 3,45 & 3,46 & 3,57 & 3,49 & 3,52 & Tinggi \\
$25-39$ & 27 & 3,64 & 3,53 & 3,54 & 3,54 & 3,72 & 3,62 & 3,60 & Tinggi \\
$40-56$ & 30 & 3,67 & 3,56 & 3,61 & 3,57 & 3,61 & 3,59 & 3,60 & Tinggi \\
\hline
\end{tabular}




\begin{tabular}{|c|c|c|c|c|c|c|c|c|c|}
\hline $56-64$ & 2 & 3,20 & 3,42 & 3,33 & 3,90 & 3,60 & 3,00 & 3,41 & Tinggi \\
\hline$>64$ & 1 & 3,61 & 3,67 & 3,50 & 3,00 & 3,60 & 3,00 & 3,40 & Tinggi \\
\hline \multicolumn{10}{|c|}{ Daerah Asal (Provinsi) } \\
\hline Riau & 69 & 3,60 & 3,55 & 3,54 & 3,50 & 3,61 & 3,54 & 3,56 & Tinggi \\
\hline Sumatera Barat & 8 & 3,72 & 3,69 & 3,63 & 3,78 & 3,68 & 3,63 & 3,68 & Tinggi \\
\hline DKI Jakarta & 5 & 3,90 & 3,83 & 3,87 & 3,68 & 3,88 & 3,60 & 3,79 & Tinggi \\
\hline DI Yogyakarta & 4 & 3,78 & 3,71 & 3,50 & 3,25 & 3,75 & 3,50 & 3,58 & Tinggi \\
\hline Jawa Barat & 4 & 3,63 & 3,58 & 3,42 & 3,85 & 3,70 & 3,58 & 3,63 & Tinggi \\
\hline Jawa Tengah & 3 & 3,63 & 3,39 & 3,17 & 3,20 & 3,60 & 3,67 & 3,44 & Tinggi \\
\hline Jawa Timur & 2 & 3,44 & 3,17 & 3,33 & 3,40 & 3,50 & 3,50 & 3,39 & Tinggi \\
\hline Kepulauan Riau & 2 & 3,06 & 3,00 & 3,17 & 3,50 & 3,20 & 3,50 & 3,24 & Tinggi \\
\hline Bali & 1 & 2,88 & 2,33 & 2,50 & 2,00 & 3,20 & 2,33 & 2,54 & Sedang \\
\hline Banten & 1 & 3,75 & 3,50 & 3,33 & 4,00 & 3,40 & 3,67 & 3,61 & Tinggi \\
\hline Sumatera Utara & 1 & 3,50 & 3,50 & 3,50 & 3,80 & 3,80 & 3,67 & 3,63 & Tinggi \\
\hline \multicolumn{10}{|c|}{ Jenjang Pendidikan } \\
\hline Perguruan Tinggi & 65 & 3,64 & 3,51 & 3,54 & 3,45 & 3,61 & 3,54 & 3,55 & Tinggi \\
\hline $\begin{array}{l}\text { Tamat } \\
\text { SMA/SMK/MA }\end{array}$ & 35 & 3,56 & 3,61 & 3,50 & 3,65 & 3,65 & 3,54 & 3,58 & Tinggi \\
\hline
\end{tabular}

\section{Jenis Profesi}

$\begin{array}{llllllllll}\text { Pegawai Swasta } & 42 & 3,71 & 3,60 & 3,60 & 3,57 & 3,67 & 3,60 & 3,62 & \text { Tinggi }\end{array}$

$\begin{array}{llllllllll}\text { Pelajar/Mahasiswa } & 29 & 3,54 & 3,53 & 3,43 & 3,46 & 3,56 & 3,49 & 3,50 & \text { Tinggi }\end{array}$

$\begin{array}{llllllllll}\text { Wirausahawan } & 11 & 3,61 & 3,58 & 3,52 & 3,47 & 3,71 & 3,73 & 3,60 & \text { Tinggi }\end{array}$

$\begin{array}{llllllllll}\text { Tidak Bekerja } & 9 & 3,64 & 3,59 & 3,57 & 3,56 & 3,64 & 3,33 & 3,56 & \text { Tinggi }\end{array}$

$\begin{array}{llllllllll}\text { Pegawai Negeri } & 7 & 3,39 & 3,29 & 3,55 & 3,57 & 3,49 & 3,48 & 3,46 & \text { Tinggi }\end{array}$

$\begin{array}{llllllllll}\text { Pegawai BUMN } & 1 & 3,88 & 3,33 & 3,67 & 3,80 & 4,00 & 4,00 & 3,78 & \text { Tinggi }\end{array}$

Pekerja Profesi

Khusus 


\begin{tabular}{lrllllllll}
\hline \multicolumn{2}{l}{$\begin{array}{l}\text { Pendapatan Bulanan } \\
\text { Rp 1.000.000 - Rp }\end{array}$} & & & & & & & & \\
10.000 .000 & 49 & 3,68 & 3,54 & 3,54 & 3,55 & 3,64 & 3,53 & 3,58 & Tinggi \\
$>$ Rp 10.000.000 & 30 & 3,58 & 3,54 & 3,51 & 3,54 & 3,54 & 3,50 & 3,51 & Tinggi \\
$<$ Rp 1.000.000 & 21 & 3,49 & 3,52 & 3,45 & 3,47 & 3,64 & 3,57 & 3,52 & Tinggi \\
Intensitas Penggunaan Traveloka & & & & & & \\
Jarang & 60 & 3,55 & 3,49 & 3,47 & 3,50 & 3,56 & 3,50 & 3,51 & Tinggi \\
Sering & 40 & 3,71 & 3,63 & 3,60 & 3,55 & 372 & 3,60 & 3,63 & Tinggi \\
\hline
\end{tabular}

Berdasarkan tabel di atas, tidak ada perbedaan skor e-service quality antara responden berjenis kelamin pria dan wanita. Responden dengan kedua jenis kelamin tersebut memiliki nilai rata-rata skor yang sama yaitu 3,56. Selanjutnya, tanggapan terhadap kualitas layanan elektronik situs web Traveloka sebagai media reservasi daring Hotel Pangeran Pekanbaru berdasarkan umur responden secara keseluruhan positif dengan skor rata-rata yang beragam. Nilai rata-rata tertinggi sebesar 3,60 berasal dari responden dengan rentang usia 25-56 tahun dan nilai terendah berasal dari responden dengan rentang usia lebih dari 64 tahun yaitu sebesar 3,40.

Perbedaan lain ditunjukkan pula oleh nilai rata-rata berdasarkan asal responden dengan semua provinsi masuk dalam kategori "tinggi”, kecuali Bali dengan nilai 2,54 yang masuk dalam kategori "sedang". Namun, karena responden yang berasal dari Bali berjumlah 1\% dari 100 orang responden, maka dapat disimpulkan bahwa nilai tersebut mewakili sebagian kecil dari keseluruhan nilai. Terkait tanggapan responden terhadap e-service quality situs web Traveloka sebagai media reservasi daring Hotel Pangeran Pekanbaru berdasarkan jenjang pendidikan, data menunjukkan bahwa seluruh nilai rata-rata menunjukkan tanggapan yang positif. 
Hasil analisis menujukkan bahwa hampir seluruh responden dengan berbagai profesi menunjukkan nilai rata-rata yang tinggi kecuali responden yang berprofesi sebagai "pekerja profesi khusus". Responden yang berprofesi khusus memiliki nilai rata-rata 2,74 yang termasuk kriteria penilaian "sedang". Namun, perlu ditekankan bahwa responden dengan profesi tersebut berproporsi 1\% dari total 100 responden.

Tanggapan responden berdasarkan kelompok-kelompok pendapatan perbulan diklasifikasikan "tinggi" yang menunjukkan bahwa responden mempunyai tanggapan yang positif terhadap kualitas layanan elektronik situs web Traveloka sebagai media reservasi daring Hotel Pangeran Pekanbaru. Nilai tertinggi didapatkan dari kelompok responden yang memiliki pendapatan Rp 11.000.000 - Rp 20.000.000 yaitu sebesar 3,61dan nilai terendah berasal dari kelompok responden dengan pendapatan bulanan lebih dari Rp 30.000.000 yaitu sebesar 3,41. Terakhir, responden yang jarang menggunakan Traveloka untuk melakukan reservasi akomodasi memberikan tanggapan nilai e-service quality yang lebih rendah, sebesar 3,51, dibandingkan dengan kelompok responden yang sering melakukan reservasi dengan Traveloka yaitu sebesar 3,63.

\section{Simpulan}

\section{Kesimpulan}

Hasil penelitian menunjukkan bahwa persepsi responden terhadap e-service quality situs web Traveloka sebagai media reservasi daring Hotel Pangeran Pekanbaru tergolong "tinggi" dengan nilai rata-rata 3,56. Hal tersebut mengindikasikan bahwa pengguna memberi tanggapan positif terhadap keseluruhan layanan yang diberikan oleh situs web Traveloka. Namun, perlu ditekankan bahwa terdapat perbedaan skor pada setiap dimensinya. Dimensi fungsionalitas serta dimensi penampilan dan presentasi situs web memiliki skor tertinggi yaitu sebesar 3,62. Di sisi lain, dimensi pemenuhan kebutuhan dan responsivitas serta dimensi keamanan pengguna situs 
web memiliki skor terendah yaitu 3,52. Meskipun keseluruhan nilai e-service quality situs web Traveloka tergolong "tinggi", jika dilihat nilai e-service quality dari profil responden, terdapat kelompok minoritas sebesar 1\% yang menjawab kualitas layanan elektronik pada kategori “sedang”. Responden yang bekerja sebagai pekerja profesi khusus, memberi tanggapan "sedang" terhadap e-service quality situs web Traveloka sebagai media reservasi Hotel Pangeran Pekanbaru dengan nilai 2,74. Selain itu, responden yang berasal dari Provinsi Bali, juga memberi tanggapan "sedang" dengan nilai 2,54. Kedua profil responden tersebut merupakan $1 \%$ dari keseluruhan responden sehingga merepresentasikan sebagian kecil dari keseluruhan nilai $e$-service quality.

\section{Rekomendasi}

Penelitian ini memiliki beberapa limitasi, salah satunya yaitu kondisi pandemi yang terjadi saat dilakukannya penelitian. Oleh karena itu, disarankan penyebaran kuesioner dilakukan secara langsung ke sampel untuk memperlancar komunikasi antar peneliti dan calon responden di waktu yang akan datang. Hal tersebut dikarenakan terdapat beberapa orang yang menolak untuk mengisi kuesioner akibat keraguan kredibilitas kuesioner daring yang diberikan. Dua dimensi e-service quality, pemenuhan kebutuhan dan responsivitas serta dimensi keamanan pengguna, situs web Traveloka sebagai media reservasi daring Hotel Pangeran Pekanbaru memiliki nilai rata-rata terendah. Oleh karena itu, diperlukan pengkajian lebih lanjut untuk mengeksplorasi sebab dari fenomena tersebut. Penelitian selanjutnya dapat mengeksplorasi e-service quality terhadap perusahaan OTA lain yang tersedia di kalangan masyarakat.

\section{Daftar Pustaka}

Cresswell, J. W. (2014). Research Design: Qualitative, Quantitative, and Mixed Methods Approaches-John W. Creswell. 
Ding, K., Choo, W. C., Ng, K. Y., \& Ng, S. I. (2020). “Employing structural topic modelling to explore perceived service quality attributes in Airbnb accommodation". International Journal of Hospitality Management. 91. 102676.

Etikan, I., Musa, S. A., \& Alkassim, R. S. (2016). Comparison of convenience sampling and purposive sampling. American journal of theoretical and applied statistics. 5(1): 1-4. DOI: $10.11648 /$ j.ajtas.20160501.11

Kaynama, S. A., \& Black, C. I. (2000). "A proposal to assess the service quality of online travel agencies: an exploratory study". Journal of professional services marketing. 21(1): 63-88.

Kim, S. H., Singh, A. J., \& Yoon, S. (2012). “Evaluating Applicability of E-service Quality in Online Hotel Bookings". FIU Hospitality Review. 30(1).

Loiacono, E. T., Watson, R. T., \& Goodhue, D. L. (2002). “WebQual: A measure of website quality". Marketing theory and applications. 13(3): 432-438.

Ip, C., Law, R., \& Lee, H. A. (2012). The evaluation of hotel website functionality by fuzzy analytic hierarchy process. Journal of Travel $\mathcal{E}$ Tourism Marketing. 29(3): 263-278. https://doi.org/10.1080/10548408.2012.666173

Oktariani, E., \& Achnes, S. (2016). “Tinjauan Loyalitas Tamu Di Hotel Pangeran Pekanbaru". Disertasi. Pekanbaru: Universitas Riau.

Peterkin, K. Y. (2014). “Online travel agencies as a source of hotel information: A content analysis". Disertation. Ljubljana: University of Ljubljana

Putri, N. N. S., Alamsyah, A., \& Widiyanesti, S. (2020). Fulfillment and Responsiveness on Online Travel Agencies Using Multiclass Classification. 2020 8th International Conference on Information and Communication Technology (ICoICT). 1-6. DOI: 10.1109/ICoICT49345.2020.9166457

Sastika, W. (2016). Analisis Pengaruh Kualitas Website (WebQual 4.0) Terhadap Keputusan Pembelian Pada Website e-commerce Traveloka. Seminar Nasional Teknologi Informasi dan Komunikasi. 2016: 649-657. ISSN: 2089-9815

Shen, C., \& Yahya, Y. (2020). “The impact of service quality and price on passenger's loyalty towards low-cost airlines: The Southeast Asia's perspective". Journal of Air Transport Management. 91. 101966.

Tsang, N. K., Lai, M. T., \& Law, R. (2010). Measuring e-service quality for online travel agencies. Journal of Travel \& Tourism Marketing. 27(3): 306-323. https://doi.org/10.1080/10548401003744743

Van Riel, A. C., Semeijn, J., \& Pauwels, P. 2004. “Online travel service quality: the role of pre-transaction services". Total Quality Management \& Business Excellence, 15(4), 475-493. 
Yoon, S. 2011. "Effects of e-Service Quality on Perceived Value, Satisfaction, and Reuse Intentions in Online Hotel Booking: Evaluating Hotel-owned and OTAs' Web sites". In proceeding. East Lansing: Michigan State University.

\section{Profil Penulis}

Ervina Wardiyanti, S.Par. merupakan alumni Program Studi S1 Pariwisata Universitas Gadjah Mada, Yogyakarta. Semasa kuliah, penulis aktif pada berbagai kegiatan akademis yang berfokus pada perkembangan teknologi dan keberlanjutan industri pariwisata. Pada tahun 2019, mendapatkan penghargaan Dr. Thanat Khoman Award dari Southeast Asian Studies, University Prince of Songkhla, setelah memaparkan pidato bertema Advancing Partnership for the Sustainable Promotion of ASEAN Tourism. Di tahun sebelumnya, penulis dipercayai untuk menjadi salah satu perwakilan pelajar UGM dalam mengikuti program pertukaran pelajar Erasmus+ Mobility Program. Saat ini penulis bekerja di salah satu perusahaan e-commerce terbesar di Asia dengan harapan untuk dapat membuka lowongan kerja industri pariwisata berbasis teknologi di masa yang akan datang.

Intan Purwandani, S.Par., M.Sc. merupakan pengajar di Program Studi S1 Pariwisata Universitas Gadjah Mada. Intan merupakan alumni program yang sama dengan tempatnya bernaung saat ini yang kemudian menyelesaikan studi masternya di Master of Leisure, Tourism, and Environment Wageningen University and Research, Belanda. Publikasi artikel ilmiahnya diantaranya membahas mengenai dampak pariwisata dan ekologi politik pariwisata telah dipublikasikan dalam beberapa jurnal seperti jurnal internasional bereputasi South East Asia Research dan jurnal nasional Gadjah Mada Journal of Tourism Studies. 